\title{
An assessment of land cover and threats in Important Bird Areas in Africa
}

\author{
GRAEME M. BUCHANAN, PAUL F. DONALD, LINCOLN D. C. FISHPOOL, \\ JULIUS A. ARINAITWE, MARK BALMAN and PHILIPPE MAYAUX
}

\section{Summary}

Over 1,200 Important Bird Areas (IBAs) have been identified in Africa, each meeting at least one of four objective criteria that identify it as an area of high conservation importance for birds. Despite their biodiversity value, many IBAs are threatened by habitat degradation and a high proportion lack legal protection. We integrate an inventory of these IBAs with remote sensing data to identify patterns that could be used to assess priorities for monitoring and conservation. Land cover composition in IBAs differed significantly from that in buffer zones of the same area immediately surrounding them and was significantly more homogeneous. Agriculture and deforestation were the most prevalent threats to IBAs, particularly in IBAs containing a high proportion of dense forest or shrub. Human population density within IBAs was no lower than that immediately outside IBAs, and was around three times higher than the average for sub-Saharan Africa. However, projected human population growth was lower than the average for sub-Saharan Africa, with the projected increase greatest in IBAs with a high proportional cover of dense forest and mosaic woodland and lowest in IBAs with a higher grassland component. Fifty seven percent of IBAs fell within or overlapped Protected Areas, though this percentage differed between different categories of IBA. IBAs that were included within Protected Areas supported a greater number of globally threatened bird species and contained proportionally more dense forest, woodland and shrub than IBAs falling outside Protected Areas. IBAs outside Protected Areas contained a high proportion of mosaic woodland and open water, suggesting that such habitats are under-protected in Africa. We suggest that because the most prevalent threats to IBAs involve changes in land cover that could be detected from satellites, remote sensing could play an important role in the monitoring of African IBAs. This would permit monitoring of a wider range of sites than is possible solely by conventional, ground-based approaches.

\section{Introduction}

As part of its global conservation strategy, BirdLife International is far advanced in the process of identifying a global network of sites (Important Bird Areas - IBAs) that are critical for the longterm survival of those bird species for which site-based conservation is appropriate. IBAs have also been shown to support many non-avian taxa of conservation significance (Brooks et al. 2001, Pain et al. 2005, Tushabe et al. 2006). Within the African region, 1,230 IBAs have been identified in 58 countries and territories, covering approximately $7 \%$ of the continent's land area (Fishpool and Evans 2001).

Identification of IBAs is based upon four standardised criteria based upon the bird species present at sites, summarised in Table I (Fishpool and Evans 2001). The identification of IBAs is the first step towards their conservation and the subsequent monitoring of their integrity and the bird populations within them is a high priority (Bennun 2002, Arinaitwe et al. 2005). While monitoring could be done using conventional field base surveys, remote sensing data could also 
Table 1. Summary of criteria used to identify IBAs (based on Fishpool and Evans 2001). Sites may qualify on multiple criteria.

\begin{tabular}{ll}
\hline Category & Criterion \\
\hline A1 Globally threatened species & $\begin{array}{l}\text { Site regularly holds significant numbers of a globally } \\
\text { threatened species, or other species of global } \\
\text { conservation concern. }\end{array}$ \\
A2 Restricted-range species & $\begin{array}{l}\text { Site is known or thought to hold a significant } \\
\text { component of the restricted-range species whose } \\
\text { breeding distributions define an Endemic Bird Area } \\
\text { (EBA) or Secondary Area (SA). }\end{array}$ \\
A3 Biome-restricted assemblage & $\begin{array}{l}\text { Site is known or thought to hold a significant } \\
\text { component of the group of species whose distributions }\end{array}$ \\
A4 Congregations & $\begin{array}{l}\text { are largely or wholly confined to one biome. } \\
\text { (i) site is known or thought to hold, on a regular } \\
\text { basis, } 1 \% \text { of a biogeographic population of }\end{array}$ \\
a congregatory waterbird species. \\
(ii) site is known or thought to hold, on a regular \\
basis, $1 \%$ of the global population of \\
a congregatory seabird or terrestrial species. \\
(iii) site is known or thought to hold, on a regular \\
basis, 20,ooo waterbirds or 10,ooo pairs of \\
seabirds of one or more species. \\
(iv) site is known or thought to exceed thresholds \\
set for migratory species at bottleneck sites.
\end{tabular}

be used. Monitoring requires, among other things, a basic understanding of both habitat (land cover) and threats. However, there has been no analysis of the land cover composition or threats across IBAs beyond a descriptive account for a subset of sites by Fishpool and Evans (2001). Here we describe variation in, and correlations between, land cover, human population growth and threats to IBAs. This study seeks to identify attributes of IBAs that appear to render them particularly threatened or poorly protected, and so in greatest need of monitoring, and discusses the extent to which remote sensing could meet such needs.

\section{Methods and materials}

\section{The African IBA Inventory}

The African IBA inventory was compiled from data provided by a range of organisations and individuals across Africa and its neighbouring islands (Fishpool and Evans 2001) and entered into the IBA module of BirdLife International's World Bird Database. For each IBA the database contains information on, among other things, physical characteristics (altitude, area), dominant land use and Protected Area status (information from the World Database of Protected Areas WDPA Consortium 2005). It also records which of 24 categories of threat affect, or were predicted to affect, each IBA, based in most cases on subjective assessments. These include both threats to habitats (e.g. vegetation clearance, agricultural encroachment, deforestation) and directly to birds (e.g. hunting, disturbance). Threat categories recognised by Fishpool and Evans (2001) were grouped into classes relating to agriculture (agricultural intensification, afforestation and silviculture, burning and shifting agriculture and reduction in land management), deforestation (including commercial deforestation, deforestation for agriculture, firewood collection, selective logging), disturbance, forest grazing, introduced species, mining, recreation and tourism, unspecified unsustainable exploitation, industrialisation/urbanisation and water management (construction/impacts of dykes, dams, barrages, drainage, dredging, filling-in). Categories of 'other' and 'unknown' were not considered 
further. The database also contains information on the number of threatened species present (based on Red List criteria; IUCN 2001), although the original identification of IBAs by Fishpool and Evans was based on the list of threatened species provided by Collar et al. (1994).

\section{Land cover data}

The Land Cover Map of Africa describes the dominant vegetation land cover at a $1-\mathrm{km}$ resolution across the whole of mainland Africa and Madagascar and was produced using SPOT VEGETATION satellite data (Mayaux et al. 2004). Digital boundaries were available for IBAs south of latitude $20^{\circ} \mathrm{N}$, covering sub-Saharan mainland Africa and Madagascar. IBAs smaller than $10 \mathrm{~km}^{2}$ were excluded from analysis of land cover or population due to their small area relative to the spatial resolution of the land cover and population data, as were those on smaller islands and those for which the boundaries had not been determined. This left 658 IBAs for which land cover data were extracted using IDRISI 3.2 (Clark Laboratories, USA). Analysis of all 26 land cover types was not possible due to the small sample sizes that would result, and to inter-correlations between variables. Instead, the 26 land cover categories were aggregated into eight main habitat classes (Appendix 1) following Mayaux et al. (2004). The inter-correlation between these variables within IBAs is summarised in Appendix 2. Land cover composition was also extracted from a buffer zone surrounding each IBA and of the same size. Since open sea was not considered in the analysis, buffer zones of coastal IBAs were smaller than the area of the IBA, though as the analyses considered proportions and not areas, this did not need to be corrected.

\section{Human population data}

Human population data were extracted for terrestrial habitats from the Gridded Population of the World (CIESIN 2004). These $5-\mathrm{km}$ resolution data on population density in 2000 and relative projected human population growth between 2000 and 2015 (calculated as: [2015 population 2000 population] $/ 2000$ population) were extracted for the area within the IBA, and for the buffer zone surrounding it (see above).

\section{Analysis}

In addition to descriptions of habitats and threats, the associations between variables were also examined. Least squares linear regression was used to model land cover in IBAs as a function of Protected Area status, human population density and projected growth, the number of criteria on which the IBA qualified and the number of globally threatened species for which the site was selected as an IBA. The proportion of each land cover type in the IBA was arcsine square roottransformed and human population density log-transformed prior to analysis. The presence or absence of each threat was modelled using binary logistic regression (specifying binomial errors and a logit link function), as a function of the presence or absence of the other recorded threats, Protected Area status, proportion of each land cover type, median altitude, area, human population density and growth, number of IBA criteria met and number of globally threatened species present.

Analysis used the Glimmix macro in SAS 8.o (SAS Institute) with the appropriate error and link functions. Each covariate, together with its quadratic term (to model curvilinear relationships) was entered individually into the model. Country was entered as a random effect to account for any within-country lack of independence between different IBAs. Area and altitude were also included as covariates where their inclusion improved the fit of the model. Where a variable explained a significant $(P<0.05)$ amount of deviance the shape of the relationship was noted. Quadratic terms were included if the combined deviance was significant with two degrees of freedom. Comparisons between the area of land cover and human population density and growth between areas within and immediately surrounding IBAs were made using paired sample t-tests. All means are presented \pm 1 SE. 


\section{Results}

\section{Land cover on IBAs}

The most extensive habitat types in IBAs were dense forest and woodlands (Figure 1). Agricultural land was the fourth largest habitat in IBAs (only fractionally smaller than shrubland), suggesting either that there has already been considerable agricultural development within IBAs, or that some agricultural activities support important bird communities. However, agricultural land was significantly less extensive in IBAs than in buffer zones immediately surrounding them. Dense forest and mosaic woodland covered a higher proportion of land within IBAs than in equivalent areas immediately surrounding them, while grasslands covered proportionally less. The extent of cover of woodland, bare soil and shrub did not differ significantly between areas within and immediately surrounding IBAs. Habitat diversity was lower within IBAs than outside (Shannon diversity index $0.63 \pm .015 \mathrm{vs} 0.73 \pm 0.015 ; t=-6.0, \mathrm{df}=768, P<0.001$ ), suggesting that IBAs tend to be more homogeneous in terms of land cover than the surrounding areas. Land cover varied between IBA selection criteria (Figure 2), with a greater cover of dense forest on sites meeting the A2 criterion than for other IBAs, especially those qualifying under A4, which were composed of proportionally more agricultural land, grassland and open water. Some $67 \%$ of IBAs qualified under category AI by supporting at least one globally threatened species (range $1-12$ ), and IBAs qualifying for at least one globally threatened species had a significantly higher cover of dense forest and mosaic woodland than IBAs not qualifying for globally threatened species (Table 2).

\section{Threats to IBAs}

The median number of threat classes per IBA was 4 (range o-8), and showed a weak tendency to increase with IBA area $\left(r_{1154}=0.066, P=0.025\right)$. Similarly, there was a positive correlation between the number of globally threatened species for which an IBA qualified and the number of threats to it $\left(r_{1212}=0.162, P<0.001\right)$. Agriculture and deforestation were identified as threats to $56 \%$ and $28 \%$ of IBAs respectively and together accounted for over $50 \%$ of the threats identified to IBAs (Figure 3), being frequently recorded in the same IBAs (Table 3). Designation of IBAs

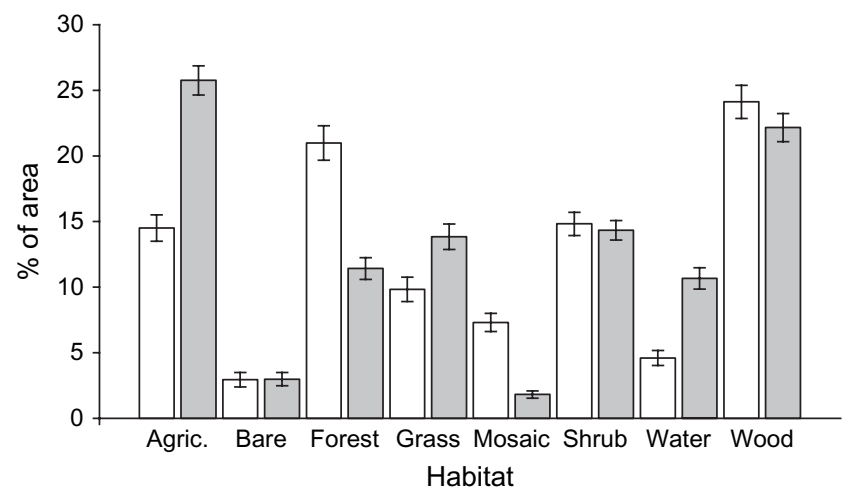

Figure 1. Percentage composition of land cover within IBAs (empty bars) and in buffer zones of the same area surrounding IBAs. Percentage composition differed between IBA and buffer zones for agriculture $(t=-9.24, \mathrm{df}=656, P<0.001)$, dense forest $(t=8.00, \mathrm{df}=656, P<0.001)$, grassland $(t=-3.16, \mathrm{df}=656, P=0.002)$, mosaic woodland $(t=7.75, \mathrm{df}=656, P<0.001)$, water $(t=-5.65, \mathrm{df}=656, P<0.001)$. Differences for bare soil $(t=-1.48, \mathrm{df}=656)$, shrub $(t=0.64, \mathrm{df}=656)$ and woodland $(t=1.59, \mathrm{df}=656)$ were all $P>0.05$. 


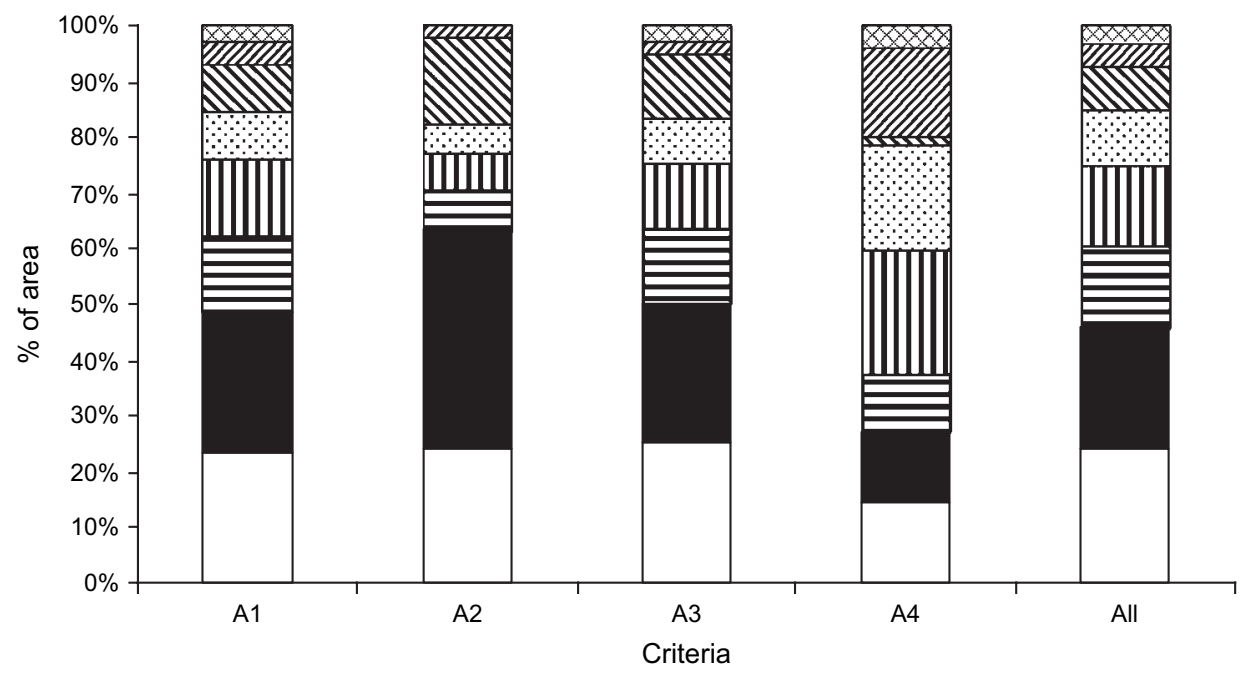

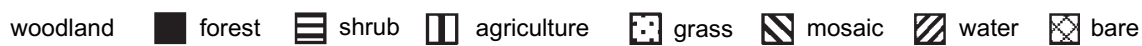

Figure 2. Proportion of African IBAs covered by each major land cover class. Criteria indicate which of the four qualifying criteria the IBA was designated under. IBAs can be designated under more than one criterion.

under multiple criteria means caution is required in interpreting differences between IBAs meeting each, but agriculture and deforestation appeared to be most prevalent in category $\mathrm{A}_{2}$ and $\mathrm{A}_{3}$ IBAs, while other threats (mainly water management and urbanisation), disturbance, and tourist related threats were more prevalent on catagory A4 sites (Figure 3).

Table 2. Summary of the shape of significant correlations between land cover, protection status, number of IBA criteria met, presence of globally threatened species (GTS) on IBAs and threats to IBAs (including human populations), with site area and country controlled for by inclusion in model. The number of symbols summarises significance $(P<0.05:+, P<0.01:++, P<0.001:+++)$. Curvilinear relationships include both linear and quadratic terms: ( indicates convex increasing, ( concave decreasing, ) convex decreasing, $\cap$ initial increasing then decreasing.

\begin{tabular}{|c|c|c|c|c|c|c|c|c|}
\hline & Agriculture & $\begin{array}{l}\text { Bare } \\
\text { soil }\end{array}$ & $\begin{array}{l}\text { Dense } \\
\text { forest }\end{array}$ & Grassland & Mosaic & Shrub & Inland Water & Woodland \\
\hline Protected Area & & & ( & - & & ++ & - - & ++ \\
\hline $\begin{array}{l}\text { Multiple IBA } \\
\text { designation }\end{array}$ & 111 & & (I) & -- & +++ & -- & & $\cap \cap \cap$ \\
\hline Presence of GTS & - - & $-\ldots$ & III & - & +++ & & - - & \\
\hline Agricultural threats & & & $\cap$ & & & $\cap$ & & 1 \\
\hline Deforestation & & & // & - & & & + & \\
\hline Disturbance & + & - & & & - & & +++ & - \\
\hline Grazing & & & // & & & & & \\
\hline Introduced spp. & ++ & & & & & & & \\
\hline \multicolumn{9}{|l|}{$\begin{array}{l}\text { Mining } \\
\text { Tourism }\end{array}$} \\
\hline & & & & & & & & \\
\hline Unsustainable. Dev. & & & + & & & & & - \\
\hline Urbanisation & & & & & & & & $\cap$ \\
\hline Water management & $\cap$ & & - & 1) & - & & + & \\
\hline Human popn & +++ & $-\ldots$ & +++ & & +++ & $\ldots$ & +++ & $\cap \cap$ \\
\hline Human popn. increase & /( & & ++ & - & ++ & & & - \\
\hline
\end{tabular}




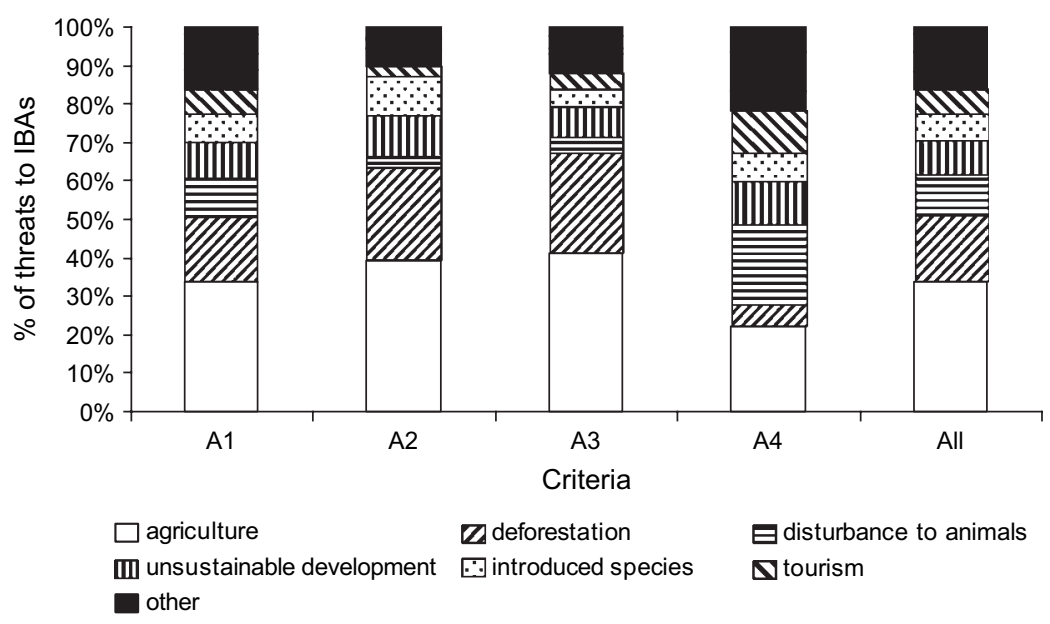

Figure 3. Proportion of African IBAs classed as being threatened by broad threat categories. Criteria represent the four qualifying criteria by which IBAs are designated. IBAs can be designated under more than one criterion.

The likelihood of an IBA being threatened by agriculture, deforestation, forest grazing or unsustainable exploitation increased with dense forest cover (Table 2). The likelihood of the threat of deforestation increased up to around $60 \%$ dense forest cover, above which it remained constant. All forest types appeared to be similarly threatened by deforestation (47.6\% of IBAs with montane and submontane forest compared to $42.2 \%$ with lowland forest only). Deforestation threat also increased exponentially with increasing human population density (Table 3). The likelihood of an IBA being classed as threatened by agriculture also increased with the proportion of shrub cover, but was not correlated with the extent of agricultural land cover (Table 2). Instead, the likelihood of threat from invasive species increased with the proportional cover of agricultural land. IBAs with open water were more likely to be identified as threatened by disturbance and water management, but within these sites, there was no relationship between water area and likelihood of threat.

Human population densities (individuals $\mathrm{km}^{-2}$ ) within IBAs were no different from those in the immediately surrounding area $(80.7 \pm 11.5$ vs $79.1 \pm 9.18, t=0.36, \mathrm{df}=768 P=0.7)$. Similarly, the projected growth in population between 2000 and 2015 did not differ $(0.36 \pm 0.011$ vs $0.34 \pm 0.011, t=0.19, \mathrm{df}=768, P=0.9)$. However, population density in and around IBAs was roughly three times higher than the 27 individuals $\mathrm{km}^{-2}$ average for sub-Saharan Africa, although projected population growth was lower than the 0.43 average for sub-Saharan Africa. Population density in IBAs increased with the extent of agricultural land cover, dense forest, mosaic woodland and water (Table 2). Projected human population growth increased with the cover of forest and mosaic woodland cover (Table 2), suggesting that IBAs dominated by these land cover types will come under increasing pressure. In contrast, a negative correlation between human population densities and the proportional cover of bare ground, shrubs, grassland or woodland, and a negative correlation between population growth and grassland and woodland cover may suggest IBAs with more extensive cover of these habitats may be less at risk. These trends were not the result of intercorrelation between initial population size and projected population change $\left(r_{658}=0.01, P=0.79\right)$. Human population densities tended to be lower in IBAs designated for globally threatened species than in those that were not $(67.4 \pm 7.65$ vs $102.1 \pm$ 32.39) although the difference was not significant $(t=1.09, \mathrm{df}=735, P=0.3)$. However, projected human population increase was significantly lower in IBAs where globally threatened species triggered selection than in other IBAs $(0.34 \pm 0.015$ vs $0.39 \pm 0.015, t=2.13, \mathrm{df}=735$, $P=0.033$ ). The positive correlation between human population increase and extent of dense 
Table 3. Summary of the shape of significant correlations between threats and protected status, number of IBA criteria met, human population \& growth and presence of globally threatened species (GTS) on IBAs and physical characteristics of sites (effects of site area, altitude and country controlled for by inclusion in models). The number of symbols summarises significance $(P<0.05:+, P<0.01:++, P<0.001:+++)$ Curvilinear relationships include both linear and quadratic terms: $($ indicates convex increasing, ) concave increasing, ( concave decreasing, $\cap$ initial increasing then decreasing.

\begin{tabular}{|c|c|c|c|c|c|c|c|c|c|c|c|}
\hline & $\begin{array}{l}\text { Agricultural } \\
\text { threats }\end{array}$ & Deforestation & Disturbance & Grazing & $\begin{array}{l}\text { Introduced } \\
\text { spp. }\end{array}$ & Mining Tourism & $\begin{array}{l}\text { Unsust. } \\
\text { Development }\end{array}$ & Urbanisation & $\begin{array}{l}\text { Water } \\
\text { mangmt. }\end{array}$ & $\begin{array}{l}\text { Human } \\
\text { popn }\end{array}$ & $\begin{array}{l}\text { Human } \\
\text { pops growth }\end{array}$ \\
\hline Agricultural threats & & & & & & & & & & 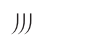 & - \\
\hline Deforestation & +++ & & & & & & & & & & + \\
\hline Disturbance to wildlife & -- & - & & & & & & & & + & \\
\hline Grazing & & +++ & & & & & & & & ++ & \\
\hline Introduced species & ++ & & & & & & & & & & -- \\
\hline Mining & & & & & & & & & & $\mu$ & /ा/ \\
\hline Tourism & - & & +++ & & & ++ & & & & & \\
\hline Unsustainable Dev. & & & & & & & & & & (/ & \\
\hline Urbanisation & & & + & - & & & & & & 1 & \\
\hline Water management. & & & & & + & & & +++ & & & -- \\
\hline Protected & & +++ & -- & +++ & & & + & - & & -- & $\cap \cap$ \\
\hline Multiple IBA designation & & & -- & & & & ++ & - & - & $\|$ & \\
\hline Presence of GTS & +++ & + & & & +++ & & +++ & & & & - \\
\hline $\begin{array}{l}\text { Mean Altitude } \\
\text { IBA Area }\end{array}$ & +++ & +++ & -- & +++ & $\ldots$ & - & --- & -- & + & & \\
\hline
\end{tabular}


forest, and the tendency for globally threatened species to occur where dense forest is more extensive might suggest projected population growth would be higher on IBAs with globally threatened species, rather than the opposite. This apparent discrepancy could be attributed to the influence of 133 IBAs lacking dense forest that support globally threatened species since there is no significant difference $(t=0.24, \mathrm{df}=602, P=0.8)$ if these sites are excluded.

\section{Protection of IBAs}

Some 690 IBAs (57\%) fell wholly or partly within Protected Areas (PAs) and were therefore at least nominally protected under national or international legislation. These IBAs tended to be larger than IBAs falling outside PAs $\left(247,400 \pm 29,500 \mathrm{~km}^{2}\right.$ vs. $86,700 \pm 12,200 \mathrm{~km}^{2} ; t=4.31$, $P<$ o.001). Only $34 \%$ of IBAs designated for their congregations of birds (category A4) were inside PAs, compared to $60 \%$ of those designated for globally threatened species (AI), $68 \%$ of those holding range restricted species ( $\mathrm{A}_{2}$ ) and $65 \%$ of those supporting biome restricted species $\left(\mathrm{A}_{3}\right)$. Among IBAs supporting globally threatened species, those within PAs supported slightly more threatened species than those falling outside $(2.46 \pm 0.010$ vs $1.92 \pm 0.102 ; t=3.54$, $\mathrm{df}=829, P<0.001$ ). IBAs within PAs were threatened more by deforestation than those outside, presumably due to their greater cover of dense forest (Tables 2 and 3 ). In addition to differences in land cover on IBAs in PAs (more shrubland and woodland but less grassland and open water than in IBAs outside PAs), human population densities were lower on IBAs that were protected compared to those lying outside PA boundaries $(50.9 \pm 5.11$ vs $148.1 \pm 45.66, t=2.90, \mathrm{df}=735$, $P=0.004)$. However, projected human population growth did not differ between IBAs within and outside PAs (o.37 \pm 0.020 vs $0.36 \pm 0.012, t=0.47, \mathrm{df}=735, P=0.6)$.

\section{Discussion}

IBAs contain proportionally more dense forest and less agricultural land than the areas immediately surrounding them, and agricultural expansion and deforestation are the most prevalent threats associated with IBAs, confirming the initial findings of Fishpool and Evans (2001). While agricultural expansion was not strongly associated with particular land cover types, the threat to IBAs from deforestation and human population growth appeared to be greater in sites with dense forest cover, the habitat most strongly associated with the presence of globally threatened species. Overall habitat diversity was greater in the areas surrounding IBAs than within them, indicating that IBAs hold patches of more uniform habitat within a matrix of more diverse, probably altered habitat types.

Threats or correlates of threats could be used to target particular conservation actions, as appropriate. The comparison of land cover data with systematic, site-specific, albeit subjective, assessments of reported or actual threats to IBAs made possible an analysis of the associations between threats and habitat types. Deforestation was reported to be almost as prevalent as agricultural expansion and intensification, and both threats were frequently recorded for the same IBAs, presumably at least in part because trees are often cleared prior to establishment of agriculture. The threat to biodiversity from deforestation is well documented (e.g. Pimm et al. 1995, Baillie et al. 2004), while habitat loss and degradation, driven primarily by deforestation, is the single most important threat to the world's birds (BirdLife International 2004). This is supported by the observed differences in land cover within IBAs relative to the areas immediately outside them, which shows that agricultural land is more extensive immediately outside IBAs and forest more extensive within them. Agricultural expansion and intensification are of particular conservation concern, with their separate impacts on biodiversity, including birds, already well documented (e.g. Donald 2004, Scharlemann et al. 2004, Green et al. 2005).

The absence of positive relationships between threats and the extent of cover of bare soil, grassland or woodland mosaic habitats (Table 2) should not necessarily be taken to indicate these habitats are less threatened, only that the threats are less likely to be recognised on these habitats. Grasslands are threatened in many locations in Africa (e.g. MacDonald et al. 1993, Reyers et al. 
2001), with demonstrated encroachment of agriculture into grassland habitats (e.g. Ndang'ang'a et al. 2002). However, the extent of grassland in IBAs was not associated in our analyses with any particular threat. This could potentially be attributable to the lack of discrimination between grassland types, such as separation of montane grasslands from less threatened lowland grasslands, although even after controlling for the effects of altitude, there was still no significant relationship between extent of grassland and agricultural threat. Additionally, inaccurate classification in the land cover map may have meant grassland was incorrectly identified as agricultural land (Mayaux et al. 2006).

Human populations and projected human population growth are often found to be greater in areas of higher biodiversity value (Balmford et al. 2001, Scharlemann et al. 2005, Luck 2007), including IBAs themselves (O'Dea et al. 2006). However, we did not detect significant differences in human population or projected growth within IBAs compared to areas immediately surrounding them. We did however find that human population densities in protected IBAs were lower than in unprotected sites, presumably as a consequence of Protected Area management. The absence of an overall difference could be genuine, and perhaps due to our use of population data at a finer resolution than in previous studies, allowing more localised comparisons to be made. However, we acknowledge that the absence of a significant difference could be attributed to these population data being insufficiently accurate for some locations, due to poor census data or inaccuracies produced as an artefact of the gridding of the data. When data are considered at coarser scales, patterns appear to support the previous studies, with population densities in and around IBAs almost three times greater than the average populations across the whole of sub-Saharan Africa. The reverse was true for population growth between 2000 and 2015, which is lower for IBAs than predicted across sub-Saharan Africa as a whole.

Just over half of the IBAs are partially or wholly contained within Protected Areas. Although IBAs overlapping PAs may appear more at risk, having more threats associated with them than unprotected sites $\left(\chi_{1}^{2}=5.55, P=0.018\right)$, the difference may simply be due to a better knowledge of threats to legally recognised sites. There is evidence that Protected Area designation is an effective means of stopping habitat degradation (Bruner et al. 2001). However, other forms of protection, such as local community management, have important roles to play (Birdlife International 2004).

\section{Monitoring IBAs}

Monitoring IBAs is central to the IBA initiative, and needed to track and respond to threats, understand the status and trends of biodiversity, and assess the effectiveness of conservation efforts (Bennun 2002, Arinaitwe et al. 2005, Bennun et al. 2005, BirdLife International 2006). The global IBA monitoring framework (BirdLife International 2006) recognises monitoring can be very simple and inexpensive (attributes that are essential for sustainability) and recommends the minimal monitoring requirement to be the collection of information on indicators for the condition of the site ('state'), threats to the site ('pressure') and conservation actions on the site ('response').

The framework also recognises that, ideally, all IBAs should be monitored regularly, and it is intended that regional and global syntheses will be carried out on a four-year cycle. Thus, the BirdLife Partnership has agreed that IBA monitoring information should be collated nationally every four years at a minimum, from 2007, although monitoring data may be collected more frequently at some sites for use at a national level.

While monitoring is already undertaken at an increasing number of IBAs by Site Support Groups (SSGs; Arinaitwe et al. 2005, BirdLife International 2007), for many this is unlikely to be possible (e.g. due to their remoteness), necessitating alternative approaches. The most frequently reported threats, and the threats most prevalent at IBAs holding globally threatened species, relate to land cover changes that are detectable using remote sensing. Deforestation and the loss of natural habitats to agriculture are already routinely measured remotely (e.g. Petit et al. 2001, Achard et al. 2002, Mayaux et al. 2005). The high proportion of IBAs for which these are recorded as major threats $(6 \%$ if combined) suggests that remote sensing could contribute much to a monitoring 
protocol for African IBAs. The potential of using remote sensing for quantified, objective assessments of land cover change on sites of conservation importance or value is underutilised, but it can be used as low cost tool in conservation assessments (e.g. Buchanan et al. 2008). A remote monitoring system would have considerable benefits, given the large size of many IBAs and of the network as a whole, the political instability in some areas of high biodiversity and the lack of resources to monitor biodiversity in Africa. Remote sensing would allow large areas to be covered on a frequent basis, especially with continuing improvements in the spatial and temporal resolution of remote sensing data and its increasing availability, filling in the gaps in the current inadequate coverage of ground based monitoring. The correlations described here between land cover and threats could be used to improving monitoring efficiency, identifying strategies appropriate to monitoring threats faced by particular IBAs. For example, remote sensing could be used to monitor forest cover in IBAs with dense forest, irrespective of whether there is a perceived threat from deforestation. In addition to informing general management, monitoring could potentially identify degradation in near-real time and hence allow timely conservation intervention.

Such a system could also allow assessments to be made of the impacts of conservation policies (Donald et al. 2007), or other policy sectors (Donald et al. 2001). It could also contribute to unilateral and international conservation policy instruments such as the Convention on Biological Diversity (CDB). Information could be used in lobbying and advocacy of governments, while comparable indices of land cover change could be used to produce regional and continental assessments of IBA state. However, it remains certain that habitat monitoring will require a range of methods, including ground surveys, as there is substantial variation in the composition of land cover and threats within IBAs.

\section{Acknowledgements}

We are very grateful to the national IBA coordinators and other contributors of data. Geoff Hilton and Paul Britten for providing the digitized IBA boundaries. Comments from two referees improved the text.

\section{References}

Achard, F., Eva, H. D., Stibig, H., Mayaux, P., Gallego, J. Richards, T. and Malingreau, J. P. (2002) Determination of deforestation rates of the world's humid tropical forests. Science 297: 999-1002.

Arinaitwe, J., Byaruhanga, A., Berruti, A. and Chirara, C. (2005) Strategy for the conservation and sustainable management of IBAs in Africa: 2005-2015. Cambridge: Birdlife International.

Baillie, J. E. M., Hilton-Taylor, C. and Stuart, S. N., (2004) IUCN Red List of threatened species. A global species assessment. Gland, Switzerland: IUCN.

Balmford, A., Moore, J. L., Brooks, T., Burgess, N., Hansen, L. A., Williams, P. and Rahbek, C. (2001) Conservation conflicts across Africa. Science 291: 2616-2619.

Bennun, L. (2002) Monitoring Important Bird Areas in Africa. A regional

framework. Cambridge, UK: BirdLife International.

Bennun, L., Matiku, P., Mulwa, R., Mwangi, S. and Buckley, P. (2005) Monitoring Important Bird Areas in Africa: towards a sustainable and scaleable system. Biodiv. Conserv. 14: 2575-2590.

BirdLife International (2004) State of the world's birds 2004: Indicators for our changing planet. Cambridge, UK: BirdLife International.

BirdLife International (2006) Monitoring Important Bird Areas: a global framework. Cambridge, UK: Birdlife International.

BirdLife International (2007) Monitoring Important bird Areas in Africa. Biodiversity status and trends report 2005. Nairobi, Kenya: ICIPE Science Press.

Brooks, T., Balmford, A., Burgess, N., Hansen, L. A., Moore, J., Rahbek, C., Williams, P., 
Bennun, L. A., Byaruhanga, A., Kasoma, P., Njoroge, P., Pomeroy, D. and Wondafrash, M. (2001) Conservation priorities for birds and biodiversity: do East African Important Bird Areas represent species diversity in other terrestrial vertebrate groups? Ostrich Suppl. 15: 3-12.

Bruner, A. G., Gullison, R. E., Rice, R. E. and Fonseca, G. A. B. (2001) Effectiveness of parks in protecting tropical biodiversity. Science 291: 125-128.

Buchanan, G. M., Butchart, S. H. M., Dutson, G., Pilgrim, J. D., Steininger, M. K., Bishop, D., and Mayaux, P. (2008) Using remote sensing to inform conservation status assessment: estimates of recent deforestation rates on New Britain and the impacts upon endemic birds. Biol. Conserv. 141: 56-66.

CIESIN, Columbia University, International Food Policy Research Institute IFPRI, the World Bank and Centro Internacional de Agricultura Tropical CIAT (2004). Global rural-urban mapping project GRUMP: Palisades, NY: CIESIN, Columbia University. $<\mathrm{http}$ //sedac.ciesin.columbia.edu/gpw $>$; (downloaded June 2005).

Collar, N. J., Crosby, M. J. and Stattersfield, A. J. (1994) Birds to watch 2: the world list of threatened birds. Cambridge, UK: Birdlife International.

Donald, P. F., Green, R. E. and Heath, M. F. (2001) Agricultural intensification and the collapse of Europe's farmland bird populations. Proc. R. Soc. London Ser. B 268: 25-29.

Donald, P. F. (2004) Biodiversity impacts of some agricultural commodity production systems. Conserv. Biol. 18: 17-38.

Donald, P. F., Sanderson, F. J., Burfield, I. J., Bierman, S. M., Gregory, R. D. and Waliczky, Z. (2007) International conservation policy delivers benefits for birds in Europe. Science 317: 810-813.

Fishpool, L. D. C. and Evans, M. (2001) Important Bird Areas in Africa and associated islands: priority sites for conservation. Cambridge, UK: Pisces Publications/ BirdLife International.

Green, R. E., Cornell, S. J., Scharlemann, J. P. and Balmford, A. (2005) Farming and the fate of wild nature. Science 307: 550-555.
IUCN (2001) IUCN Red List categories and criteria: Version 3.1. Gland, Switzerland: IUCN.

Luck, G. W. (2007) The relationships between net primary productivity, human population density and species conservation. J. Biogeog. 34: 201-212.

Macdonald, I. A. W., Van Wijk, K. and Boyd, L. (1993) Conservation priorities in South Africa. Stellenbosh: Southern African Nature Foundation.

Mayaux, P., Bartholomé, E., Fritz, S. and Belward, A. (2004) A new land-cover map of Africa for the year 2000. J. Biogeog 31: 861-877.

Mayaux, P., Holmgren, P., Achard, F., Eva, H. and Stibig, H. J. (2005) Tropical forest cover change in the 1990s and options for future monitoring. Philos. Trans. R. Soc. Lond. B. 360: 373-84.

Mayaux, P., Eva, H., Galleco, J., Strahler, A. H., Herold, M., Agrawal, S., Naumov, S., De Miranda, E. E., Di Bella, C. M., Ordoyne, C., Kopin, I. and Roy, P. S. (2006) Validation of the Global Land Cover 2000 map. IEEE Trans. Geosci. Remote Sens. 44: 1728-1739.

Ndang'ang'a, P. K., du Plessis, M. A., Ryan, P. G. and Bennun, L. A. (2002) Grassland decline in Kinangop Plateau Kenya: implications for conservation of Sharpe's Longclaw Macronyx sharpei. Biol. Conserv. 107: 341-350.

O'Dea, N. Araujo, M. B. and Whittaker, R. J. (2006) How well do important bird areas represent species and minimize conservation conflict in the tropical Andes? Divers. Distrib. 12: 205-214.

Pain, D. J., Fishpool, L., Byaruhanga, A., Arinaitwe, J. and Balmford, A. (2005) Biodiversity representation in Uganda's forest IBAs. Biol. Conserv. 125: 133138.

Petit, C., Scudder, T. and Lambin, E. (2001) Quantifying processes of land-cover change by remote sensing: resettlement and rapid land-cover changes in south-eastern Zambia. Int. J. Remote Sens. 22: 34353456.

Pimm, S. L., Russell, G. J., Gittleman, J. L. and Brooks, T. M. (1995) The future of biodiversity. Science 269: 347-350. 
Reyers, B., Fairbanks, D. H. K., Van Jaarsveld, A. S. and Thompson, M. (2001) Priority areas for the conservation of South African vegetation: a coarse-filter approach. Divers. Distrib. 7: 79-95.

Scharlemann, J. P. W., Green, R. E. and Balmford, A. (2004) Land-use trends in Endemic Bird Areas: global expansion of agriculture in areas of high conservation value. Glob. Change Biol. 10: 2046-2051.

Scharlemann, J. P. W., Balmford, A. and Green, R. E. (2005) The level of threat to restricted-range bird species can be predicted from mapped data on land use and human population. Biol. Conserv. 123: 317-326.

Tushabe, H., Kalema, J., Byaruhanga, A., Asasira, J., Ssegawa, P., Balmford, A., Davenport, T., Fjeldsa, J., Friis, I., Pain, D., Pomeroy, D., Williams, P. and Williams, C. (2006) A nationwide assessment of the biodiversity value of Uganda's important bird areas network. Conserv. Biol. 20: 85-99.

WDPA Consortium (2005) World Database on Protected Areas 2005. CD-ROM. Cambridge, UK: IUCN/UNEP-WCMC.

GRAEME M. BUCHANAN*, PAUL F. DONALD

Royal Society for the Protection of Birds, The Lodge, Sandy, Bedfordshire, SG19 2DL, U.K.

LINCOLN D. C. FISHPOOL, MARK BALMAN

BirdLife International, Wellbrook Court, Girton Road, Cambridge, CB3 oNA, U.K.

\section{JULIUS A. ARINAITWE}

Africa Partnership Secretariat, P. O. Box 3502-00100 Nairobi, Kenya.

\section{PHILIPPE MAYAUX}

Institute for Environment and Sustainability, Joint Research Centre of the European

Commission, TP 440, I-2120, Ispra, Italy.

*Author for correspondence; e-mail: graeme.buchanan@rspb.org.uk

Received 3 December 2007; revision accepted 9 June 2008 
Appendix 1. The amalgamated land cover classes from Land Cover Map of Africa (Mayaux et al. 2004) used in the analysis.

\begin{tabular}{ll}
\hline Category & LCMA class \\
\hline Agriculture & Irrigated croplands \\
Agriculture & Croplands \\
Agriculture & Croplands with open woody vegetation \\
Agriculture & Tree crops \\
Bare soil & Bare rock \\
Bare soil & Salt hardpans \\
Bare soil & Sandy desert and dunes \\
Bare soil & Stony desert \\
Dense forest & Montane forest \\
Dense forest & Closed deciduous forest \\
Dense forest & Closed evergreen lowland forest \\
Dense forest & Degraded evergreen lowland forest \\
Dense forest & Mangrove \\
Dense forest & Submontane forest \\
Dense forest & Swamp forest \\
Grasslands & Open grassland with sparse shrubs \\
Grasslands & Mixed Closed grassland \\
Grasslands & Open grassland \\
Grasslands & Sparse grassland \\
Grasslands & Swamp bushland and grassland \\
Inland water & Inland open water \\
Mosaic woodland & Mosaic forest/croplands \\
Mosaic woodland & Mosaic forest/savanna \\
Shrub & Open deciduous shrubland \\
Woodland & Deciduous shrubland with sparse trees \\
Woodland & Deciduous woodland \\
\hline & \\
\hline
\end{tabular}

Appendix 2. Spearman rank correlations of inter relationships between the different land cover classes. Italics indicate $P<0.01$ and bold indicates $P<0.001$.

\begin{tabular}{|c|c|c|c|c|c|c|c|}
\hline & Agriculture & Bare soil & Dense forest & Grassland & Mosaic & Shrub & Inland water \\
\hline Bare soil & 0.06 & & & & & & \\
\hline Dense forest & -0.33 & -0.22 & & & & & \\
\hline Grassland & 0.16 & 0.45 & -0.36 & & & & \\
\hline Mosaic & -0.30 & -0.21 & 0.57 & -0.34 & & & \\
\hline Shrub & 0.28 & -0.06 & -0.37 & 0.05 & -0.27 & & \\
\hline Inland water & 0.25 & 0.19 & -0.16 & 0.21 & -0.14 & 0.05 & \\
\hline Woodland & -0.14 & -0.23 & -0.15 & -0.36 & -0.14 & 0.31 & -0.11 \\
\hline
\end{tabular}

